Abstracta Iranica Abstracta Iranica

Revue bibliographique pour le domaine irano-aryen

Volume 25 | 2004

Comptes rendus des publications de 2002

\title{
War, Politics and Society in Afghanistan 1978-1992. First published by C. Hurst \& Co. London. Printed in India, 2000, $320 \mathrm{p}$.
}

Tchanguiz Pahlavan

\section{(2) OpenEdition}

1 Journals

Édition électronique

URL : http://journals.openedition.org/abstractairanica/5188

DOI : 10.4000/abstractairanica.5188

ISSN : 1961-960X

Éditeur :

CNRS (UMR 7528 Mondes iraniens et indiens), Éditions de l'IFRI

Édition imprimée

Date de publication : 15 mai 2004

ISSN : 0240-8910

Référence électronique

Tchanguiz Pahlavan, « War, Politics and Society in Afghanistan 1978-1992. First published by C. Hurst \& Co. London. Printed in India, 2000, 320 p. », Abstracta Iranica [En ligne], Volume 25 | 2004, document 337, mis en ligne le 15 mars 2006, consulté le 25 septembre 2020. URL : http://

journals.openedition.org/abstractairanica/5188; DOI : https://doi.org/10.4000/abstractairanica.5188

Ce document a été généré automatiquement le 25 septembre 2020.

Tous droits réservés 


\title{
War, Politics and Society in Afghanistan 1978-1992. First published by C. Hurst \& Co. London. Printed in India, 2000, $320 \mathrm{p}$.
}

\author{
Tchanguiz Pahlavan
}

1 This book mainly deals with the evolution of military and political tactics during the period concerned. The author believes that while the mutual relationship of political, social and military aspects of the Afghan Resistance has been analysed satisfactorily, the same has not been done with regard to the pro-Soviet regime in Kabul. Therefore, he is willing to pay attention to the military aspects of this period.

2 The book is divided into four parts. In Part One, he deals with the Limits of Sovietization. Part Two of the book is about the Afghan regular armed forces: Reconstruction, Reorganization and Structural Limits. In Part Three, called "The Pacification Policy", we see the efforts made for national reconciliation.

3 The last part is about the role of the militias. There is some useful information concerning the age groups in the PDAP, the percentage of party members in the armed forces, educational levels of party members, membership at local level, ethnic composition of the PDAP, military operations carried out by Afghan armed forces etc.

\section{INDEX}

Thèmes : 13.2. Afghanistan 


\section{AUTEURS}

TCHANGUIZ PAHLAVAN

Münster 